Original Research

Acoustic Stapedial Reflexes in Newborns

\title{
Findings of Acoustic Stapedial Reflex Test in Newborns with and without Risk Factor
}

\author{
Görkem Ertuğrul ${ }^{1}$, Gonca Sennaroğlu ${ }^{1}$ \\ ${ }^{1}$ Hacettepe University, Faculty of Health Sciences, Department of Audiology
}

\begin{abstract}
Objectives: The aim of this study was to determine the presence rate of acoustic stapedial reflexes (ASR) and to assess the test-retest reliability of ASR at a $1000 \mathrm{~Hz}$ probe tone in newborns with and without risk factor. Materials and Methods: Screening Transient Evoked Otoacoustic Emission (TEOAE), Automated Auditory Brainstem Response (AABR), tympanometry and ASR tests were performed on 59 ears with risk factor (research group) and 44 ears without risk factor (control group) within $0-2$ weeks following birth. And one month later, tympanometry and ASRs measurements were repeated. Results: In terms of ASR thresholds, there is no significant difference between the two groups ( $p>0.05)$. Detection rate of ipsilateral ASRs were higher than those of contralateral ASRs in the first assessment for both groups. Conclusion: Ipsilateral ASRs in neonates can be obtained in the early postnatal period, but contralateral ASRs can be detected late, especially one month after birth. Since ASR provides information about entire hearing system, it is an essential diagnostic test in newborns.
\end{abstract}

Key Words: acoustic reflex, newborn, risk factor

Corresponding Author: Görkem Ertuğrul, ertugrulgorkem@ gmail.com , Hacettepe Üniversitesi Sağlık Bilimleri Fakültesi Odyoloji Bölümü Sıhhiye/ Ankara Tel: 03123051667 


\title{
Original Research
}

Yenidoğanlarda Akustik Stapedial Refleks

\section{Risk Faktörü Olan ve Olmayan Yenidoğanlarda Akustik Stapedial Refleks}

\section{Testi Bulguları}

\author{
Görkem Ertuğrul ${ }^{1}$, Gonca Sennaroğlu ${ }^{1}$ \\ ${ }^{1}$ Hacettepe University, Faculty of Health Sciences, Department of Audiology
}

\begin{abstract}
Özet
Amaç: Bu çalışmanın amacı, $1000 \mathrm{~Hz}$ probe tone kullanılarak risk faktörü olan ve olmayan, yenidoğanlarda akustik stapedial reflekslerin (ASR) elde edilebilme oranlarının belirlenmesi, ASR testinin test- tekrar test güvenirliğinin incelenmesidir. Gereç ve Yöntem: 0-2 haftalık yenidoğanlardan risk faktörü olan 59 kulağa (araştırma grubu) ve risk faktörü olmayan 44 kulağa (kontrol grubu) tarama Transient Otoakustik Emisyon (TEOAE), Automated Auditory Brainstem Response (AABR), timpanometri ve ASR testleri yapılmıștır. Bir ay sonra da timpanometri ve ASR ölçümleri tekrar edilmiştir. Bulgular: Akustik stapedial refleks eşikleri açısından, iki grup arasında anlamlı bir fark bulunamamıştır ( $p>0.05$ ). Her iki grubun ilk değerlendirmesinde ipsilateral ASR'lerin elde edilme oranı, kontralateral ASR'lerin elde edilme oranından daha yüksek bulunmuştur. Sonuç: Yenidoğanlarda ipsilateral ASR'ler doğum sonrası erken dönemlerde elde edilebilmektedir. Ancak kontralateral ASR'ler özellikle doğumdan bir ay sonrası gibi daha geç dönemlerden elde edilebilmektedir. Akustik stapedial refleksler işitme sisteminin bütünü hakkında bilgi sağladığından, ASR testi yenidoğanlarda yapılması gereken temel bir tanisal testtir.
\end{abstract}

Anahtar Kelimeler: akustik refleks, yenidoğan, risk faktör

Corresponding Author: Görkem Ertuğrul, ertugrulgorkem@ gmail.com , Hacettepe Üniversitesi Sağl1k Bilimleri Fakültesi Odyoloji Bölümü Sıhhiye/ Ankara Tel: 03123051667 


\section{Introduction}

Acoustic stapedial reflex (ASR) is the contraction of musculus stapedius in response to acoustic stimulus (Mazlan \& et. al., 2009a). The presence of acoustic reflexes provides information about the afferent auditory system, auditory brainstem function, and integrity of VII. cranial nerve (nervous facialis) and also middle ear function (Feeney, 2005). The stapedius reflex which is innervated by the stapedial branch of VII. cranial nerve, is a bilateral reflex which occurs in both parts of the head. Bilateral ASR allows monaural stimulus to elicit bilateral contraction of the m. stapedius (Margolis, 1993; Wiley, 1997). Ipsilateral and contralateral ASRs each follow different pathways. This difference results from superior olivary complex in contralateral ASR (Katz, 2002; Wiley, 1997).

Acoustic stapedial reflex measurements play a major role in the Newborn Hearing Screening Programme (NHSP) to detect auditory neuropathy in newborns. However, the ASR test is not commonly used to assess infants. Because there is no normative data for ASRs at $1000 \mathrm{~Hz}$ probe tone in newborns (Kei, 2012). It was reported that ipsilateral ASRs at $2 \mathrm{kHz}$ have more test-retest reliability than BroadBand Noise (BBN) in six weeks-old infants with normal hearing function (Mazlan, Kei \& et. al., 2009b).

The Joint Committee on Infant Hearing defined some risk factors for NHSP in 2007 (JCIH, 2007). These risk factors were used in this study.

The goal of this study was to determine the presence rate of ASR and to assess test-retest reliability of ASR at $1000 \mathrm{~Hz}$ probe tone in newborns with and without risk factor.

\section{Materials and Methods}

The study was conducted at the Hacettepe University ENT/Audiology and Speech Pathology unit and approved by the Ethics Committee of Hacettepe University (LUT 12/13713). Written informed consent was obtained from newborns' parents participating in the study. Fifty-two newborns (103 ears) passed NHSP and had normal hearing. One newborn could not pass NHSP in one of his ears during the first assessment because of the middle ear problem and flat tympanogram. So this ear was excluded from the study. Thirty newborns (59 ears) with risk factors were appointed to the research group and twenty-two newborns without risk factors formed the control group. Due to flat tympanogram, in study group five ears and control group one ear were not included in analysis at second assessment. In addition, three ears in the control group and two ears in the study group were not included to in the second 
assessment because these infants were crying and being too active. These infants could not be evaluated, although attempts were made to reassess the after they had slept and became quiet again. Eight infants from the research group were not brought to follow up one month later, therefore 16 ears were not re-tested. as a result, 26 ears were excluded from the study.

\section{Materials}

Tympanometry was made by GSI Tympstar Version 2 Middle Ear Analyzer in which the pressure level changed between +200 and -400 dapa. A $1000 \mathrm{~Hz}$ probe tone was used for the tympanogram and some parameters of acoustic immitance, such as tympanometric peak pressure (TPP), equivalent ear canal volume $\left(\mathrm{V}_{\mathrm{ea}}\right.$ and peak static acoustic admittance $\left(\mathrm{Y}_{\mathrm{tm}}\right)$ values, were obtained for each participant.

Acoustic Stapedial Reflex (ASR) Test was measured by GSI Tympstar Version 2 Middle Ear Analyzer at a $1000 \mathrm{~Hz}$ probe tone. Ipsilateral ASR thresholds were measured at $500 \mathrm{~Hz}, 2000 \mathrm{~Hz}$ and BBN and contralateral ASR thresholds were measured at $2000 \mathrm{~Hz}, 4000$ $\mathrm{Hz}$ and BBN in this study. ASR thresholds were repeated three times at the same intensity level in all stimuli.

Screening Transient Otoacoustic Emission (TEOAE) was measured by GN Otometrics MADSEN Accuscreen PRO screening emission device. Non-linear $60 \mathrm{~Hz}$ click stimulus was used at $40 \mathrm{~dB}$ SPL (decibel Sound Pressure Level). According to infant's ear canal size, either a $3 \mathrm{~mm}$ or $4 \mathrm{~mm}$ probe was used. Results of screening TEOAE were obtained automatically as REFER or PASS.

Automated Auditory Brainstem Response (AABR) test was performed by MADSEN Accuscreen at $35 \mathrm{~dB}$ click stimulus in the $2000-4000 \mathrm{~Hz}$ frequency range. The measurements were made by insert earphone. The device had three kind of electrode. The positive electrode was put on the forehead, ground electrode on the cheekbone and negative electrode on the nape. The results of AABR were obtained automatically as PASS or REFER.

\section{Procedure}

At first step, as a requirement of hearing screening programme, TEOAE and AABR tests were performed bilaterally in both groups. Infants who passed the hearing screening and had normal hearing [bilateral TEOAE and AABR (+)] were included in this study.

And then, tympanometry with $1000 \mathrm{~Hz}$ probe tone was performed on all infants in each group. If newborns had a normal tympanogram and normal middle ear function, their ipsilateral and contralateral ASRs using $1000 \mathrm{~Hz}$ probe tone were measured. 
After one month, all tests were repeated in each group. During the assessments, all newborns were evaluated during natural sleep, while they lay down in their pushchairs or in their mother's arms to provide reliability and ease of the measurement.

\section{Statistical Analysis}

SPSS version 15.0 computer programme was used for statistical analysis (IBM SPSS Statistics, IBM Corporation; Chicago, IL, USA). Pearson's Chi-square tests were used to compare categorical data. Paired Samples t-test was used to compare within groups and Intraclass Correlation Coefficient (ICC) was used to detect test-retest reliability of ASR test. A value of $\mathrm{p}<0.05$ was accepted as statistically significant.

\section{Results}

Acoustic stapedial reflex results of 30 infants (59 ears) with risk factors and 22 infants (44 ears) without risk factors were compared 0-2 weeks after birth and one month later. There was no significant difference between two groups for gender ( $p>0.05)$. In terms of the means of age at testing and gestational age, there is a significant difference between groups in first and second assessment $(\mathrm{p}<0.05)$. Means of age in study group were higher than those of control group, but the mean of gestational age of study group was lower than control group. The study group includes term pre-term and premature newborns. Table 1 shows demographic information od participants.

Table 1. Descriptive Statistics for Both Group

\begin{tabular}{c|c|ccccccc}
\hline \multirow{2}{*}{ Group } & $\begin{array}{c}\text { Age 1 } \\
\text { (day) }\end{array}$ & $\begin{array}{c}\text { Age 2 } \\
\text { (day) }\end{array}$ & $\begin{array}{c}\text { Birth } \\
\text { Weight } \\
\text { (gr) }\end{array}$ & $\begin{array}{c}\text { NICU } \\
\text { (day) }\end{array}$ & $\begin{array}{c}\text { Bilirubin } \\
\text { Level }\end{array}$ & $\begin{array}{c}\text { Photo } \\
\text { therapy } \\
\text { (day) }\end{array}$ & $\begin{array}{c}\text { Gestational } \\
\text { Age } \\
\text { (week) }\end{array}$ \\
\hline \multirow{6}{*}{ Control } & Mean & 2.9 & 35.85 & 3393.63 & - & - & - & 38.49 \\
& SD & 2.17 & 6.75 & 616.79 & - & - & - & 1.14 \\
& Min. & 1 & 26 & 2130 & - & - & - & 36 \\
& Max. & 11 & 48 & 5200 & - & - & - & 40 \\
& $\mathrm{~N}$ & 44 & 40 & 44 & 44 & 44 & 44 & 44 \\
\hline \multirow{5}{*}{ Research } & Mean & 9.1 & 39.82 & 2861.01 & 4.42 & 15.38 & 2.93 & 37.29 \\
& SD & 5.79 & 13.7 & 625.81 & 6.64 & 5.62 & 3.03 & 2.53 \\
& Min. & 1 & 24 & 1300 & 0 & 7.88 & 1 & 28 \\
& Max. & 21 & 57 & 3800 & 30 & 25.25 & 10 & 40.1 \\
\hline $\mathrm{p}$ & 59 & 34 & 59 & 59 & 30 & 16 & 59 \\
\hline $\mathrm{p}<0.05:$ statistically significant & $0.00 *$ & $0.00 *$ & 0.41 & & & $0.00^{*}$ \\
\hline
\end{tabular}


The distribution of risk factors and percentages in the study group are illustrated in Table 2. Infants demonstrated only one risk factor, two risk factors or more than two risk factors (multiple risk factors). Twelve infants in the study group were observed multiple risk factors including premature birth, family history of SNHL, children of consanguineous parents, exchange transfusion, hyperbilirubinemia, usage of ototoxic medicine, low birth weight, >5 days in Newborn Intensive Care Unit (NICU), genetic disease and ECMO. In this study, bacterial meningitis, neurodegenerative disorder and infection were not observed in any newborns.

Table 2. Distribution of Risk Factor in Research Group

\begin{tabular}{lcc}
\hline Risk Factors & $\begin{array}{c}\text { N } \\
\text { (Newborn) }\end{array}$ & $\begin{array}{c}\text { Percent } \\
(\%)\end{array}$ \\
\hline Hyperbilirubinemia & 3 & 10 \\
Relationship between parents & 4 & 13,33 \\
Family history of SNHL & 4 & 13,33 \\
Following in NHCU more than 5 days & 3 & 10 \\
Hyperbilirubinemia + >5 days NHCU & 1 & 3,33 \\
Premature + >5 days NHCU & 1 & 3,33 \\
Ototoxic medicine + >5 days NHCU & 2 & 6,67 \\
Multiple Risk Factor $(>2)$ & 12 & 40 \\
\hline Total & 30 & 100 \\
\hline
\end{tabular}

There was no significant difference between the means of TTP, $\mathrm{Y}_{\mathrm{tm}}$ and $\mathrm{V}_{\mathrm{ea}}$ of both groups in the two assessments $(\mathrm{p}>0.05)$.

There was no significant difference between ASR thresholds of both groups at the first and second assessments ( $>0.05$ ) (Table 3). Although no significant differences were found, the mean of ipsilateral ASR thresholds for both groups was higher than that of contralateral ASR thresholds in both first and second assessments.

A significant difference was found between the means of the ipsilateral BBN ASR thresholds in the control group between the first and second assessments $[\mathrm{t}(15)=-2.556$, $\mathrm{p}<0.05]$. Similarly, in both assessments of the study group, there was a significant difference between means of the ipsilateral BBN ASR thresholds of the research group $[\mathrm{t}(16)=-2.675$, $\mathrm{p}<005]$. No significant differences were found for other parameters $(p>0.05)$. 
Table 3. Ipsilateral and Contralateral ASR Thresholds Using $1000 \mathrm{~Hz}$ Probe Tone for Both

\begin{tabular}{|c|c|c|c|c|c|c|c|c|}
\hline & \multicolumn{8}{|l|}{ Assessment } \\
\hline & \multirow{2}{*}{$\begin{array}{l}\text { Acoustic Stapedial } \\
\text { Reflexes }\end{array}$} & \multicolumn{3}{|c|}{ Control Group } & \multicolumn{3}{|c|}{ Research Group } & \multirow{2}{*}{$\mathrm{p}$} \\
\hline & & Mean & $\mathrm{SD}$ & $\mathrm{N}$ & Mean & $\mathrm{SD}$ & $\mathrm{N}$ & \\
\hline \multirow{6}{*}{ 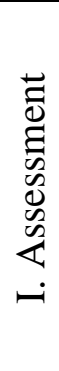 } & ipsilateral $500 \mathrm{~Hz}$ & 92,22 & 9,83 & 27 & 95,31 & 8,32 & 32 & 0,19 \\
\hline & ipsilateral $2000 \mathrm{~Hz}$ & 80,71 & 10,24 & 28 & 83,25 & 7,47 & 40 & 0,24 \\
\hline & ipsilateral $\mathrm{BBN}$ & 64,46 & 9,65 & 28 & 66,21 & 9,4 & 41 & 0,45 \\
\hline & contralateral $2000 \mathrm{~Hz}$ & 98,43 & 13,87 & 16 & 99,78 & 13,09 & 23 & 0,76 \\
\hline & contralateral $4000 \mathrm{~Hz}$ & 90,33 & 9,9 & 15 & 94,76 & 12,49 & 21 & 0,26 \\
\hline & contralateral BBN & 76,9 & 16,23 & 21 & 73,75 & 14,18 & 28 & 0,47 \\
\hline \multirow{6}{*}{ 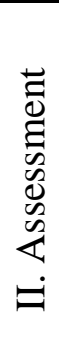 } & ipsilateral $500 \mathrm{~Hz}$ & 97 & 9,01 & 25 & 96,33 & 10,25 & 15 & 0,83 \\
\hline & ipsilateral $2000 \mathrm{~Hz}$ & 83,88 & 10,03 & 27 & 88,15 & 9,45 & 19 & 0,15 \\
\hline & ipsilateral BBN & 70 & 9,27 & 26 & 71,05 & 8,42 & 19 & 0,69 \\
\hline & contralateral $2000 \mathrm{~Hz}$ & 98,26 & 10,19 & 26 & 99,09 & 12 & 11 & 0,83 \\
\hline & contralateral $4000 \mathrm{~Hz}$ & 96,19 & 9,86 & 21 & 96,11 & 10,54 & 9 & 0,98 \\
\hline & contralateral BBN & 76,36 & 11,56 & 22 & 77 & 9,48 & 10 & 0,88 \\
\hline
\end{tabular}

In the study group, the reversed ASR ratio was higher than the control group in both evaluations (Table 4). In this study, the reversed acoustic reflexes were accepted as reflex absent and statistical analysis was made by this hypothesis.

Table 4. Findings of Reversed ASR in Both Assessment

\begin{tabular}{|c|c|c|c|c|c|c|c|}
\hline & & \multicolumn{3}{|c|}{ I. Assessment } & \multicolumn{3}{|c|}{ II. Assessment } \\
\hline \multicolumn{2}{|l|}{ Group } & $\begin{array}{c}\mathrm{N} \\
\text { (ear) }\end{array}$ & $\begin{array}{c}\text { Percent } \\
(\%)\end{array}$ & $\begin{array}{l}\text { Total } \\
\text { (ear) }\end{array}$ & $\begin{array}{c}\mathrm{N} \\
\text { (ear) }\end{array}$ & $\begin{array}{c}\text { Percent } \\
(\%)\end{array}$ & $\begin{array}{l}\text { Total } \\
\text { (ear) }\end{array}$ \\
\hline \multirow{6}{*}{ Control } & ipsilateral $500 \mathrm{~Hz}$ & 9 & 20.5 & 44 & 11 & 29.7 & 37 \\
\hline & ipsilateral $2000 \mathrm{~Hz}$ & 9 & 20.5 & 44 & 8 & 22.2 & 36 \\
\hline & ipsilateral BBN & 8 & 18.2 & 44 & 9 & 25.7 & 35 \\
\hline & contralateral $2000 \mathrm{~Hz}$ & 11 & 26.2 & 42 & 4 & 12.9 & 31 \\
\hline & contralateral $4000 \mathrm{~Hz}$ & 10 & 23.8 & 43 & 6 & 20.0 & 30 \\
\hline & contralateral BBN & 14 & 33.3 & 42 & 7 & 22.6 & 31 \\
\hline \multirow{6}{*}{ Research } & ipsilateral $500 \mathrm{~Hz}$ & 18 & 32.7 & 59 & 17 & 50.0 & 34 \\
\hline & ipsilateral $2000 \mathrm{~Hz}$ & 13 & 23.6 & 55 & 14 & 41.2 & 34 \\
\hline & ipsilateral BBN & 12 & 21.8 & 55 & 13 & 39.4 & 33 \\
\hline & contralateral $2000 \mathrm{~Hz}$ & 13 & 25.5 & 51 & 8 & 36.4 & 22 \\
\hline & contralateral $4000 \mathrm{~Hz}$ & 15 & 29.4 & 51 & 10 & 45.5 & 22 \\
\hline & contralateral BBN & 12 & 23.5 & 51 & 10 & 45.5 & 22 \\
\hline
\end{tabular}


For some infants, ASR stimulus was not tested in both groups for both evaluations because infants woke up, cried or were restless. Therefore, the number of evaluated total ears in Table 4 (similarly in Table 5 and Table 6) was different for each ASR stimulus.

Generally, unobservable ASR rates of both study and control group in the first assessment decreased in the second assessment. Only unobservable ipsilateral BBN rates of the research group at the second assessment increased compared to the first assessment (Table 5). In the first evaluation, although three ears from the control group had no observable ASR at the maximum intensity level, ipsilateral and contralateral ASRs for all stimuli were obtained in the second evaluation.

Table 5. Findings of Unobservable ASR in Both Assessment

\begin{tabular}{|c|c|c|c|c|c|c|c|}
\hline & & \multicolumn{3}{|c|}{ I. Assessment } & \multicolumn{3}{|c|}{ II. Assessment } \\
\hline \multicolumn{2}{|l|}{ Group } & $\begin{array}{c}\mathrm{N} \\
\text { (ear) }\end{array}$ & $\begin{array}{c}\text { Percent } \\
(\%)\end{array}$ & $\begin{array}{l}\text { Total } \\
\text { (ear) }\end{array}$ & $\begin{array}{c}\mathrm{N} \\
(\mathrm{ear})\end{array}$ & $\begin{array}{c}\text { Percent } \\
(\%)\end{array}$ & $\begin{array}{l}\text { Total } \\
\text { (ear) }\end{array}$ \\
\hline \multirow{6}{*}{ Control } & ipsilateral $500 \mathrm{~Hz}$ & 8 & 18.2 & 44 & 1 & 2.7 & 37 \\
\hline & ipsilateral $2000 \mathrm{~Hz}$ & 7 & 15.9 & 44 & 1 & 2.8 & 36 \\
\hline & ipsilateral BBN & 8 & 18.2 & 44 & 0 & - & 35 \\
\hline & contralateral $2000 \mathrm{~Hz}$ & 15 & 35.7 & 42 & 1 & 3.2 & 31 \\
\hline & contralateral $4000 \mathrm{~Hz}$ & 17 & 40.5 & 43 & 3 & 10.0 & 30 \\
\hline & contralateral BBN & 7 & 16.7 & 42 & 2 & 6.5 & 31 \\
\hline \multirow{6}{*}{ Research } & ipsilateral $500 \mathrm{~Hz}$ & 9 & 9.1 & 59 & 2 & 5.9 & 34 \\
\hline & ipsilateral $2000 \mathrm{~Hz}$ & 2 & 3.6 & 55 & 1 & 2.9 & 34 \\
\hline & ipsilateral BBN & 2 & 3.6 & 55 & 2 & 6.1 & 33 \\
\hline & contralateral $2000 \mathrm{~Hz}$ & 15 & 29.4 & 51 & 3 & 13.6 & 22 \\
\hline & contralateral $4000 \mathrm{~Hz}$ & 15 & 29.4 & 51 & 3 & 13.6 & 22 \\
\hline & contralateral BBN & 11 & 21.6 & 51 & 2 & 9.1 & 22 \\
\hline
\end{tabular}

In the first assessment, ipsilateral ASRs were more observable than contralateral ASRs for both groups for all stimuli levels. However, an observable rate of contralateral ASRs in the control group increased dramatically in the second assessment (Table 6). There were significant differences only between the percentage of presence of the contralateral ASRs at $2000 \mathrm{~Hz}$ and $4000 \mathrm{~Hz}$ for the control group in both assessments $(p<0.05)$. The detection rate of contralateral $2000 \mathrm{~Hz}$ and $4000 \mathrm{~Hz}$ ASRs nearly doubled in the second 
evaluation (Figure 1). Conversely, because of the missing data, the detection ratio of ASR for the study group declined in the second evaluation ( $p>0.05)$.

Table 6. Rates of ASRs Presence in Both Assessment

\begin{tabular}{|c|c|c|c|c|c|c|c|}
\hline \multirow{2}{*}{ Group } & & \multicolumn{3}{|c|}{ I. Assessment } & \multicolumn{3}{|c|}{ II. Assessment } \\
\hline & & $\begin{array}{c}\mathrm{N} \\
\text { (ear) } \\
\end{array}$ & $\begin{array}{c}\text { Percent } \\
(\%)\end{array}$ & $\begin{array}{l}\text { Total } \\
\text { (ear) } \\
\end{array}$ & $\begin{array}{c}\mathrm{N} \\
\text { (ear) } \\
\end{array}$ & $\begin{array}{c}\text { Percent } \\
(\%)\end{array}$ & $\begin{array}{l}\text { Total } \\
\text { (ear) } \\
\end{array}$ \\
\hline \multirow{6}{*}{ Control } & ipsilateral $500 \mathrm{~Hz}$ & 27 & 61.4 & 44 & 25 & 67.6 & 37 \\
\hline & ipsilateral $2000 \mathrm{~Hz}$ & 28 & 63.6 & 44 & 27 & 75 & 36 \\
\hline & ipsilateral BBN & 28 & 63.6 & 44 & 26 & 74.3 & 35 \\
\hline & contralateral $2000 \mathrm{~Hz}$ & 16 & $38.1 *$ & 42 & 26 & $83.9 *$ & 31 \\
\hline & contralateral $4000 \mathrm{~Hz}$ & 15 & $35.7 *$ & 43 & 21 & $70 *$ & 30 \\
\hline & contralateral BBN & 21 & 50 & 42 & 22 & 71 & 31 \\
\hline \multirow{6}{*}{ Research } & ipsilateral $500 \mathrm{~Hz}$ & 32 & 58.2 & 59 & 15 & 44.1 & 34 \\
\hline & ipsilateral $2000 \mathrm{~Hz}$ & 40 & 72.7 & 55 & 19 & 55.9 & 34 \\
\hline & ipsilateral BBN & 41 & 74.5 & 55 & 18 & 54.5 & 33 \\
\hline & contralateral $2000 \mathrm{~Hz}$ & 23 & 45.1 & 51 & 11 & 50 & 22 \\
\hline & contralateral $4000 \mathrm{~Hz}$ & 21 & 41.2 & 51 & 9 & 40.9 & 22 \\
\hline & contralateral BBN & 28 & 54.9 & 51 & 10 & 45.5 & 22 \\
\hline
\end{tabular}

*: $\mathrm{p}<0.05$; statistically significant

Figure 1. Rates of ASRs presence in control group

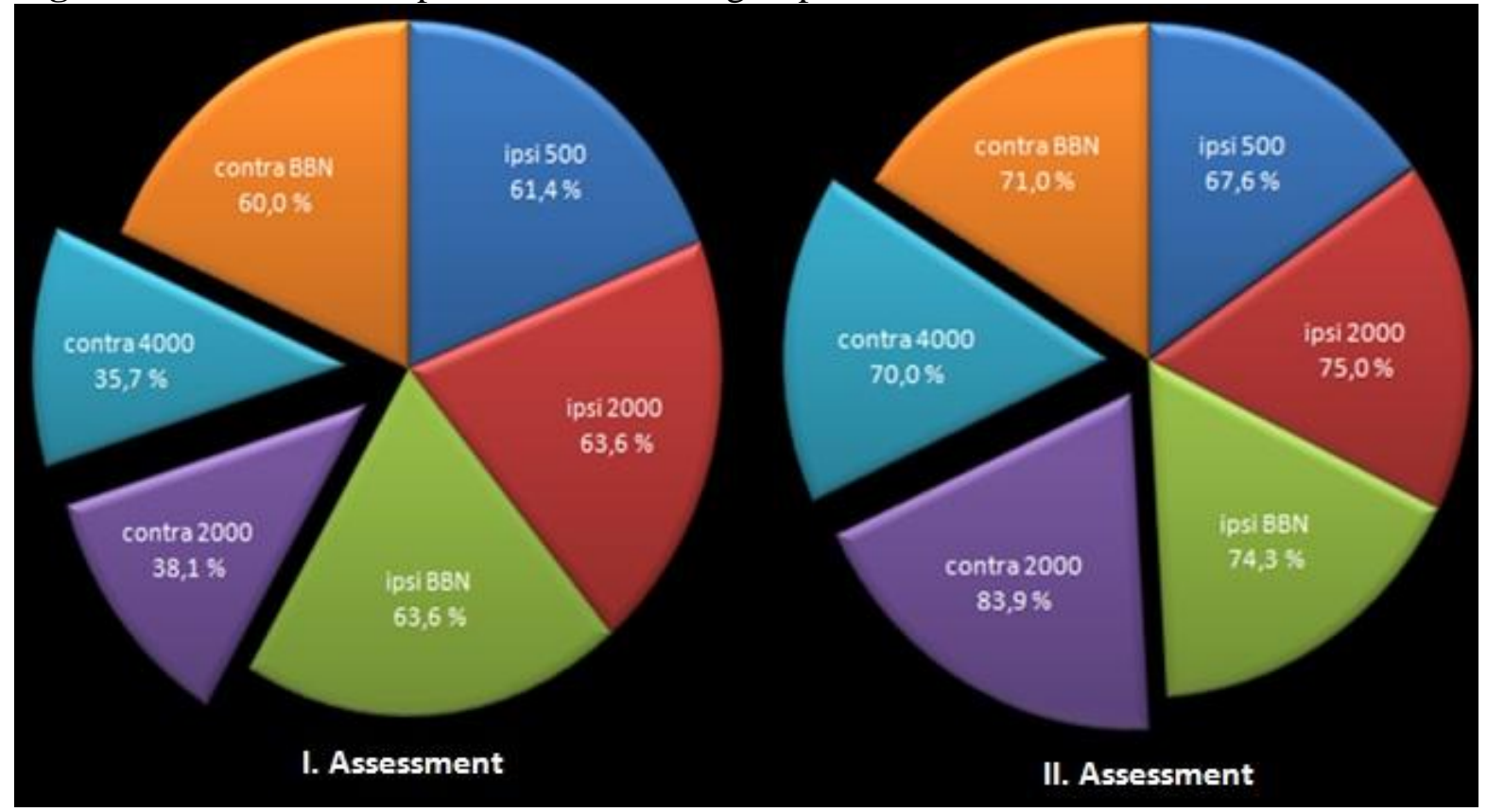


Table 7 illustrated that the test-retest reliability of ipsilateral and contralateral ASR thresholds for both groups in all evaluations were markedly high. However, ICC of the contralateral $4000 \mathrm{~Hz}$ and BBN were not significantly different due to the missing data in the second evaluation $(\mathrm{p}>0.05)$.

Table 7. Intraclass Coefficient Correlation for First and Second Assessment

\begin{tabular}{|c|c|c|c|c|}
\hline & \multicolumn{2}{|c|}{ Control Group } & \multicolumn{2}{|c|}{ Research Group } \\
\hline & $\begin{array}{c}\text { I. } \\
\text { Assessment }\end{array}$ & $\begin{array}{c}\text { II. } \\
\text { Assessment }\end{array}$ & $\begin{array}{c}\text { I. } \\
\text { Assessment }\end{array}$ & $\begin{array}{c}\text { II. } \\
\text { Assessment }\end{array}$ \\
\hline ipsilateral $500 \mathrm{~Hz}$ & $0.88 *$ & $0.83 *$ & $0.73 *$ & $0.98 *$ \\
\hline ipsilateral $2000 \mathrm{~Hz}$ & $0.88 *$ & $0.80 *$ & $0.70 *$ & $0.92 *$ \\
\hline ipsilateral BBN & 0.65 & $0.88 *$ & $0.85 *$ & $0.97 *$ \\
\hline contralateral $2000 \mathrm{~Hz}$ & $0.88 *$ & $0.94 *$ & $0.94 *$ & $0.96 *$ \\
\hline contralateral $4000 \mathrm{~Hz}$ & $0.95 *$ & $0.98 *$ & $0.94 *$ & 0.00 \\
\hline contralateral BBN & $0.77 *$ & $0.88 *$ & $0.92 *$ & 0.64 \\
\hline
\end{tabular}

*: $\mathrm{p}<0.05$ statistically significant correlation

\section{Discussion}

The aim the current study was to determine the presence rate of ASRs and to assess test- retest reliability of ASR using a $1000 \mathrm{~Hz}$ probe tone in newborns with and without risk factors.

In literature, studies pointed out that tympanometry and ASR should be obtained with a $1000 \mathrm{~Hz}$ probe tone in infants under nine months. Since $1000 \mathrm{~Hz}$ probe tone is more sensitive than low frequency probe tones to distinguish the middle ear pathologies in infants (Hoffmann, 2013; Son, 2012; Swanepoel, 2007). On the contrary to the results of (Ciardo \& et. al., 2003; Ochi, 2002), both reversed ipsilateral and contralateral ASR were observed in each group at both assessments in the current study. The proportion of reversed ipsilateral ASRs increased in the second assessment for the control group. However, in the study group, the rate of both the reversed ipsilateral and contralateral ASR rise in the second assessment owing to missing data (flat tympanograms, more activity, crying, an awake state and failure of the other assessment). Kleindienst (2008) reported that normal ASRs were observed in $83 \%$ of infants and reversed ASRs were detected in $6 \%$ of newborns and reported that reversed ASR was a myogenic response associated with the rise of intensity level. 
Ipsilateral ASR thresholds were measured at $500 \mathrm{~Hz}, 2000 \mathrm{~Hz}$ and BBN and contralateral ASR thresholds were measured at $2000 \mathrm{~Hz}, 4000 \mathrm{~Hz}$ and BBN in this study. Because it has been demonstrated that the most reliable responses for ipsilateral ASR were obtained at $500 \mathrm{~Hz}, 2000 \mathrm{~Hz}$ and BBN (Kei, 2012) and for contralateral ASR, at $2000 \mathrm{~Hz}$ and $4000 \mathrm{~Hz}$ (McMillan, 1985). It is thought that an acoustic reaction can affect ASR results. The literature suggests that the stimulus frequency must be different from probe tone frequency to minimize the acoustic reaction (Kei, 2012). To prevent the acoustic reaction, ASR using a $1000 \mathrm{~Hz}$ probe tone was not measured at a $1000 \mathrm{~Hz}$ stimulus. Maximum intensity level for ASR was determined as $120 \mathrm{~dB}$ HL (decibel Hearing Level) and acceptable value for ASR was $0.04 \mathrm{mmho}$ (Kei, 2012). ASR thresholds were repeated three times at the same intensity level in all stimuli.

The etiology of the reversed ASR has not been completely demonstrated (Ciardo \& et. al. , 2003; Katz, 2002; McMillan, 1985; Yavuz, 2007). There have been a lot of reasons of reversed ASR in literature, such as the construction of the muscles tensor tympani (Ochi, 2002; Ried, 2000), an acoustic mechanic reaction inside the ear canal (Ciardo \& et. al., 2004; Ciardo \& et. al., 2005; Yavuz, 2007), an artefact, a non-physiological effect caused by a connection between the probe and the acoustic cavity (Ciardo \& et. al., 2003). In our view, reversed ASR is a physiological artefact. In this study, reversed ASRs were accepted as "reflex absent" and were excluded from the study to avoid a confounding variable for the rate of ASR presence.

Both absence rate of ASRs decreased for each group from the first assessment to the second assessment. Only the absence rate of the ipsilateral BBN did not change at the second assessment for the study group. It was an interesting finding that ASR responses that were not found in three infants with normal middle ear function in the control group were observed in the first assessment at maximum intensity level, although measurements were repeated three times by the researcher at different periods of the same day. Nevertheless, all of the ipsilateral and contralateral ASRs were detected in these infants at the second assessment. As a result, these findings may suggest that the ASR arc could have been late activated in these infants. More studies are needed to address this question.

ASR is one of the most useful audiological tests and gives valuable information about middle ear problems, cochlear hearing loss, auditory neuropathy spectrum disorder, retrocochlear pathology, central auditory processing disorder and facial nerve paralysis, and it is equally as effective in newborns as it is in adults (Seewald, 2011). 
Many studies suggested that ASR in newborns should be measured with a highfrequency probe tone, especially a $1000 \mathrm{~Hz}$ probe tone because ASR is more reliable and the rate of ASR presence is higher at high frequencies probe tones than low frequencies probe tones (Barajas, 1981; Bennett, 1982; McMillan, 1985; Sprague, 1985; Stream, 1978; Sutton, 2007). Previous researches state that presence rate of the ipsilateral and contralateral ASR at $220 \mathrm{~Hz}$ probe tone is lower than a $660 \mathrm{~Hz}$ or a $1000 \mathrm{~Hz}$ probe tone in infants (Barajas, 1981; Bennett, 1982; Himelfarb, 1978; Hirsch, 1992; Katz, 2002; Keith, 1978; Kleindienst, 2008; McMillan, 1985; Sprague, 1985; Stream, 1978; Sutton, 2007; Weatherby, 1980). In consideration of the studies in the literature, we used only a $1000 \mathrm{~Hz}$ probe tone to evaluate ASR in newborns. Owing to the low rate of presence of ASR at a $226 \mathrm{~Hz}$ probe tone in newborns, the $226 \mathrm{~Hz}$ probe tone was not used in this study.

Although the rate of presence of ipsilateral ASRs was higher than contralateral ASRs for both groups in the first assessment, the rate of ASR presence increased for only the control group. However, there were significant differences between only contralateral $2000 \mathrm{~Hz}$ and $4000 \mathrm{~Hz}$ compared with the rate of ASR presence for the two assessments $(\mathrm{p}<0.05)$ whereas the rate of presence ipsilateral ASRs did not change significantly in both assessments. As a result, we suggest that ipsilateral ASRs can be measured in the early period of life, but the presence of contralateral ASRs increases later.

Kleindienst (2008) reported that $87 \%$ of infants had ipsilateral ASR in $500-4000 \mathrm{~Hz}$ and BBN using a $1000 \mathrm{~Hz}$ probe tone. McMillan and colleagues (McMillan, 1985) observed that contralateral $1000-2000 \mathrm{~Hz}$ ASRs with a $660 \mathrm{~Hz}$ probe tone (76\%) were three times more obtainable than with a $220 \mathrm{~Hz}$ probe tone (24\%). They could not find any significant differences between the first and second assessment of the presence rate of ipsilateral ASR. If the probe tone increases, the presence rate of the ASR increases in the same way, whereas ASR thresholds decrease (Bennett, 1982; Katz, 2002; McMillan, 1985; Weatherby, 1980).

Sprague and colleagues (1985) reported that ASR thresholds in noise stimulus were significantly lower than tonal stimulus and contralateral ASR thresholds were greater than ipsilateral ASRs. These findings supported our study. Similarly, we found that ipsilateral ASR thresholds were lower than contralateral ASR and the mean of ASR with BBN stimulus was smaller than tonal stimuli.

When the bandwidth increases, ASR thresholds decreases. Therefore, it is expected that ASR thresholds in noise stimuli will be low. In addition, it is thought that the small ear 
canal volume of newborns and high- frequency probe tone can cause this difference (Hirsch, 1992).

Most researchers supported our findings that BBN ASR thresholds are lower than all tonal ASRs at approximately $15-20 \mathrm{~dB}$. The reason for this difference has not yet been demonstrated, but it is thought that bandwidth of the stimulus that activates reflexes might be involved (Abahazi, 1977; Bennett, 1982; Margolis, Popelka, 1975; Mazlan \& et. al., 2009a; Popelka, 1974).

Critical band mechanism is effective in the appearance of ASRs and critical bandwidth of ASR for $1 \mathrm{kHz}$ is wider than observations in physiological research; for example, when the fundamental frequency is $1 \mathrm{kHz}$, the critical bandwidth of ASR is nearly $700 \mathrm{~Hz}$ (Flottorp, 1971; Popelka, 1974). ASR thresholds correlate with the stimulus region of the basilar membrane. Changes of bandwidth in ASR data facilitate to detection of hearing impairment. ASR thresholds in wideband noise are higher than tonal stimulus in SNHL (Flottorp, 1971).

Unexpectedly in our study, only ipsilateral BBN thresholds means increased significantly in the second assessment for both the control and research groups $(\mathrm{p}<0.05)$. This result may occur, if ipsilateral BBN, but no other ASR thresholds, are affected by maturation.

In our study, test-retest reliability of the ASR test was found to be quite high in both groups, which is similar to other results in the literature (Kei, 2012; Mazlan \& et. al., 2009b; Mazlan \& et. al., 2009a). However, we could find no significant differences in the ICC for contralateral $4000 \mathrm{~Hz}$ and BBN because of the missing data in the second assessment.

\section{Conclusion}

Hearing screening with only TEOAE in newborns is not sufficient, because TEOAE only gives physiological information about external hair cell function and does not evaluate the complete hearing system. In addition, TEOAE can be obtained in infants whose cochlea is normal, but in whom the eighth cranial nerve is absent or in those with auditory neuropathy. Therefore, TEOAE tests do not fully indicate normal peripheral auditory system in newborns. In conditions under which an AABR cannot be obtained, we suggest using the ASR test in newborns to provide detection of auditory neuropathy or eighth nerve aplasia in the early period of life.

Acoustic Stapedial Reflex, which has quite high test-retest reliability, is an essential audiological diagnostic test battery in newborns because it gives clinicians more information 
about the entire hearing system. Ipsilateral ASRs in neonates can be obtained in the early postnatal period, but contralateral ASRs can be detected late, especially one month after birth.

\section{Conflict of Interest}

The authors declare no conflict of interest.

\section{Financial Support}

This study was supported by Hacettepe University Scientific Research Projects Coordination Unit (012B12401001). Görkem Ertuğrul took only financial support to get consumables such as electrodes, writing materials, contra arc by Hacettepe University Scientific Research Projects Coordination Unit.

Nobody else took extra payment to produce the manuscript. 


\section{References}

Abahazi, D. A., Greenberg, H. J. (1977). Clinical acoustic reflex threshold measurements in infants. Journal Of Speech And Hearing Disorders, 514-519.

Barajas, J., Olaizola, F., Tapia, M.C., Alacron, J.L., Alaminos, D. (1981). Audiometric study of the neonate: Impedance audiometry, behavioral responses and brain stem audiometry. Audiology, $20,42-52$.

Bennett, M., Weatherby, L.A. (1982). Newborn acoustic reflexes to noise and pure-tone signals. Journal of Speech and Hearing Research, 25, 383-387.

Ciardo, A., Garavello, W. Rossetti A. (2003). The reversed ipsilateral acoustic reflex: clinical features and kinetic analysis. Acta Otolaryngol (Stockh), 123, 65-70.

Ciardo, A., Garavello, W., Gaini, R. M. (2004). Acoustic tensor tympany response and vestibularevoked myogenic potential. Laryngoscope, 114, 1513-1514.

Ciardo, A., Garavello, W., Uva, M. et. al. (2005). Reversed ipsilateral acoustic reflex: a study on subjects treated with muscle relaxants. Ear \& Hearing, 26, 96-103.

Feeney, M. P., Sanford, C.A. (2005). Detection of the acoustic stapedius reflex in infants using wideband energy reflectance and admittance. Journal of the American Academy of Audiology, 6, 278-290.

Flottorp, G., Djupesland, G., Winther, F. (1971). The acoustic stapedius reflex in relation to critical bandwidth. Journal of the Acoustical Society of America, 49, 457-461.

Himelfarb, M. Z., Shannon, E., Popelka, G. R., Margolis, R. H. (1978). Acoustic reflex evaluation in neonates. In G. S.E., G. T. Mencher (Ed.), Early diagnosis of hearing loss. New York: Grune \& Stratton, 109-119.

Hirsch, J. E., Margolis, R. H., Rykken, J. R. (1992). A Comparison of Acoustic Reflex and Auditory Brain Stem Response Screening of High-Risk Infants Ear and Hearing, 13(3).

Hoffmann, A. D., D., Rosslau, K., Knief, A., Dinnesen, A. Z., Schmidt, C.M. . (2013). Feasibility of $1000 \mathrm{~Hz}$ tympanometry in infants: Tympanometric trace classification and choice of probe tone in relation to age. International Journal of Pediatric Otorhinolaryngology, 77, 1198-1203.

Joint Committee on Infant Hearing Position Statement: Principles and Guidelines for Early Hearing Detection and Intervention Programs. (2007). Pediatrics, 120, 898-921.

Katz, J. (2002). Handbook of clinical audiology ( Fifth Edition ed.): Lippincott Williams \& Wilkins, 205-232.

Kei, J. (2012). Acoustic stapedial reflexes in healthy neonates: Normative data and test-retest reliability. Journal of the American Academy of Audiology, 23, 46-56.

Keith, R. W., Bench, R. J. (1978). Stapedial reflex in neonates. Scandinavian Audiology, 7, 187-191.

Kleindienst, S. (2008). High frequency $(1000 \mathrm{~Hz})$ ipsilateral acoustic stapedial reflexes in neonates. (A Doctoral Thesis), United States, ProQuest LLC.

Margolis, R. H. (1993). Detection of hearing impairment with the acoustic stapedius reflex. Ear and Hearing, 14(1), 3-10.

Margolis, R. H., Popelka, G. R. (1975). Static and dynamic acoustic 1mpedance measurements in infant ears. Journal of Speech and Hearing Research, 18, 435-443.

Mazlan, R., Kei, J., Hickson, L., Curtain, S. et. al. (2009b). Test-retest reliability of acoustic reflex test in 6-week-old healthy infants. The Australian and New Zealand Journal of Audiology, 31, 2532. 
Mazlan R, K. J., Hickson L. (2009a). Test-retest reliability of the acoustic stapedial reflex test in healthy neonates. Ear \& Hearing, 30, 295-301.

McMillan, P. M., Bennett, M. J., Marchanti C. D., Shurin, P.A. (1985). Ipsilateral and contralateral acoustic reflexes in neonates. Ear and Hearing, 6(6), 320-324.

Ochi, K., Ohashi, T. ve Kinoshita, H. . (2002). Acoustic tensor tympani response and veslibularevoked myogenic potential. Laryngoscope, 1(12), 2225-2229.

Popelka, G. R., Karlovich, R. S., Wiley, T.L. (1974). Acoustic reflex and critical bandwidth. Journal of the Acoustical Society of America, 55, 4.

Ried, E., Ojeda, J. P., Agurto, M. et.al. (2000). Inverted acoustic reflex in patients with otosclerosis. Ada Otorinolaringol Esp, 51, 463-467.

Seewald, R., Tharpe, A. M. (2011). Comprehensive Handbook of Pediatric Audiology (pp. 365-388): Plural Publishing Inc, 365-88

Son, E. J., Park, Y.U, Kim, J.H., Hong, S.A., Lim, H. Y., Choi, J.Y., Lee, W.S. . (2012). Classification of trace patterns of 226- and $1000-\mathrm{Hz}$ tympanometry in healthy neonates. Auris Nasus Larynx, 39, 455-460.

Sprague, B. H., Wiley, T. L., Goldstein, R. (1985). Tympanometric and acoustic-reflex studies in neonates. Journal of Speech and Hearing Research, 28, 265-272.

Stream, R. W., Stream, K. S., Walker, J. R., Breningstall, G. (1978). Emerging characteristics of the acoustic reflex in infants. Otolaryngology, 86, 628- 636.

Sutton, G. J. (2007). Usefulness of acoustic reflexes still unproven in newborns and young infants. Journal of the American Academy of Audiology, 18(2), 187-189.

Swanepoel, D. W., Werner, S., Hugo, R., Louw, B., Owen, R., Swanepoel, A. (2007). High frequency immittance for neonates: a normative study. Acta Oto-Laryngologica, 127, 49-56.

Weatherby, L. A., Bennett, M.J. (1980). The neonatal acoustic reflex. Scandinavian Audiology, 9, 103-110.

Wiley, T. L., Fowler, C. G. (1997). Acoustic Immitance Measures in Cilinical Audiology. SanDiegoLondon: Singular Publishing Group, 39-66.

Yavuz, H., Caylakli, F., Cağıcı, C.A.,Yılmaz,İ., Ataş, A., Ozluoglu, L. (2007). Reversed ipsilateral acoustic reflex pattern. The Journal of Otolaryngology, 36(5), 274-281. 